\section{Pharaoh's Daughter: The Adoptive Mother's Sacrifice}

Feminist Theology 202I, Vol. 29(2) 102-II2 (C) The Author(s) 2020

Article reuse guidelines: sagepub.com/journals-permissions DOI: I0.1 I77/0966735020965 I64 journals.sagepub.com/home/fth

(SAGE

\title{
Cat Quine
}

University of Nottingham, UK

\begin{abstract}
In Exodus 2, Moses has two mothers; his Hebrew mother, who nurses him and the daughter of Pharaoh, who financially supports his Hebrew mother, adopts him, and names him. Pharaoh's daughter appears in scholarly discussions, yet little attention is given to her role as mother of Moses. Indeed, this motherhood is downplayed in the biblical texts, and also in biblical scholarship, wherein the daughter of Pharaoh is absent from many discussions of biblical mothers and is at times relegated beneath the birthmother in commentaries. This article argues that we should remember and celebrate the daughter of Pharaoh as a mother of Moses.
\end{abstract}

\section{Keywords}

Daughter of Pharaoh, sacrifice, Exodus 2, adoption, Moses

\section{Introduction}

Exodus 2:1-10 narrates the dramatic account of Moses' mother hiding her baby son in a waterproofed basket and floating it down the Nile in an attempt to protect him from Pharaoh's edict that all Hebrew baby boys should be killed (Exod. 1:15-22). As the baby floats down the Nile, his sister watches from a distance, and upon the daughter of Pharaoh finding him, she suggests that the baby's birthmother act as the boy's wet nurse (Exod. 2:4-8). The daughter of Pharaoh agrees to pay the mother to nurse the baby (Exod. 2:9), and when he is weaned, she adopts him and names him Moses (Exod. $2: 10)$. This brief passage has attracted scholarly interest for a number of reasons, including similarities with traditions of exposed infants protected by the gods, such as the

\section{Corresponding author:}

Cat Quine, University of Nottingham, Nottingham NG7 2RD, UK.

Email: Cat.Quine@nottingham.ac.uk 
birth legend of Sargon of Akkad. ${ }^{1}$ In addition, the many ironies of the passage have been noted, such as the Nile acting as a vehicle of salvation for Moses rather than a means of death, as Pharaoh commanded (Exod. 1:22), and the fact that a member of Pharaoh's own household brings up the man who would go on to bring trouble to Egypt. ${ }^{2}$ Finally, some commentators observe the dominant role played by women in this narrative; the plot revolves around the mother of the baby, his sister, and Pharaoh's daughter, while the male baby floats between them. ${ }^{3}$ Through their actions, these three unnamed women defy Pharaoh and save the life of a boy - as Fretheim states, 'daughters bring the son through death to life'. ${ }^{4}$

Yet, I argue that the daughter of Pharaoh is not given the credit she deserves, neither in the biblical text nor in biblical scholarship. This woman is a fascinating character, for not only does she play a vital role in Moses' survival and upbringing, she also represents a rare example of an adoptive mother in the Hebrew Bible. She goes against a Pharaonic edict and adopts a child from another race, only to lose him later on when Moses turns his back on Egypt and leads the Israelites out of his former homeland. The desire for sons is a central theme in biblical texts, and stories of women going to great lengths to procure a son, such as Sarah, Rachel, and Hannah, readily spring to mind. ${ }^{5}$ Yet, caught up in the fast-moving story of the Exodus, few stop to ponder the daughter of Pharaoh's loss; Israel may have gained a leader, but a mother lost her son. The lack of attention paid to the daughter of Pharaoh's motherhood comes in part from the biblical text, which does not refer to the daughter of Pharaoh as 'mother' - that term is reserved for his birthmother, for reasons which are explored below. Biblical scholarship has seemingly followed this convention and on the

1. Most scholars agree that although Exod. 2:1-10 bears some resemblance to traditions such as those of Sargon (wherein an infant is exposed, protected by the gods, brought up by peasants, and progresses to importance), it also has notable differences, including the absence of a deity in the narrative, the importance of Moses' name, and the fact that he was brought up in the royal household rather than in obscurity. See, for example, Martin Noth (1962) Exodus: A Commentary. OTL; London: SCM Press, 26-27; George W. Coats (1999) Exodus 1-18. FOTL IIA; Cambridge: Eerdmans, 28; John I. Durham (1987) Exodus. WBC 3; Nashville: Thomas Nelson, 15; Cornelis Houtman (1993) Exodus, Volume 1. HCOT; Leuven: Peeters, 290-291. For further examples of the exposed child motif see Donald B. Redford (1967) The Literary Motif of the Exposed Child (Cf. Ex. ii 1-10). Numen 14: 209-228. Note also Childs' observation that the sister watching over him tempered any harshness of Moses' exposure; Brevard S. Childs (1974) Exodus: A Commentary. OTL; London: SCM Press, 18.

2. For example, Terence E. Fretheim (2010) Exodus. Interpretation; Louisville, KY: John Knox Press [repr. 1991]), 37-38.

3. For example, J. Cheryl Exum (1983) "You shall let every daughter live": A study of Exodus 1:8-2:10. Semeia 28: 63-82; Carol Meyers (2005) Exodus. NCBC; Cambridge: Cambridge University Press, 39, 42.

4. Fretheim (2010) Exodus, 37. In light of this, the nomenclature "daughter of Pharaoh" probably foreshadows the tension to come - she is both related to Pharaoh (evil), yet a daughter (in Exod. 1-2, defiant, clever, brave). In her name the Pharaoh is dominant, yet in her actions she is the dominant one.

5. See the discussion of various ways of avoiding childlessness in John Byron (2010) EGLBS presidential address: Childlessness and ambiguity in the ancient world. Proceedings EGLBS \&. MWSBL 30: 17-46. 
whole prioritises the birthmother's importance over that of the daughter of Pharaoh, despite acknowledging her important adoptive role. Even when her motherhood is recognised, it does not seem to be afforded any emotion or power and readers are not invited to reflect on her as a mother. In addition, the daughter of Pharaoh is often absent from studies that focus on mothers in the Bible and ancient Israel. For example, Exum's excellent chapter on 'The (M)other's Place' deals only with the matriarchs, wherein, although Genesis provides rich fodder for the discussion, I cannot help but feel that the daughter of Pharaoh (who is literally mother and other) would have added to the discussion. ${ }^{6}$ Somewhat similarly, Kozlova offers a rich exploration of maternal grief in the Hebrew Bible, yet neither of Moses' mothers appear, and both birthmother and adoptive mother are absent from Fuchs' discussion of 'The Literary Characterization of Mothers' ${ }^{7}$ What follows, therefore, emphasises the daughter of Pharaoh as a mother and explores the reasons why this motherhood is downplayed. Notably, unlike the story of Esther, the daughter of Pharaoh's adoption of Moses does not work out well: he grows up, kills a man and flees the country, only to come back and divorce himself completely from his adoptive family and nation. In the modern world, the course of adoption rarely runs smoothly and many adoptive parents - and children - may well recognise some of the difficulties of their own experiences in the Moses story. While Moses is narratively redeemed from his difficulties, however, and becomes a symbol for adopted children to look up to, the daughter of Pharaoh fades from view, her sacrifice forgotten. This paper argues that remembering and reflecting on the daughter of Pharaoh's adoptive motherhood may prove productive for modern readers of the biblical texts and also adds a sense of loss into the Exodus narrative that is not otherwise obvious.

\section{Two Women, One Mother?: Exodus 2: I- 10}

The woman who places her baby son in a basket on the Nile, the sister who watched over him, and the daughter of Pharaoh who was drawn to him at the Nile are all unnamed in Exod. 2:1-10. Consequently, as Meyers notes, the rhetorical potential of the passage is heightened. ${ }^{8}$ The baby boy is eventually given the name Moses, yet the women remain unnamed, characterised by their relation to the male child (birthmother, sister, adopter). In many ways, the two adult women stand in contrast: on the one hand a Levite, Hebrew woman who has to give up her child in fear of his life, and on the other, an Egyptian princess who defies the pharaonic order and rescues the child despite realising he is a Hebrew. Their joint care for the male baby, however, brings them together. When the daughter of

6. J. Cheryl Exum (2016), The (m)other's place. In: J. Cheryl Exum (ed.) Fragmented Women: Feminist (Sub)versions of Biblical Narratives. 2nd ed. T\&T Clark Cornerstones; London: Bloomsbury T\&T Clark, 69-115.

7. See Ekaterina E. Kozlova (2017) Maternal Grief in the Hebrew Bible. Oxford: Oxford University Press. The absence of the women of Exodus 2 is understandable on the one hand, especially given that the authors of Exodus do not explore the mothers' grief at losing their sons. On the other hand, the lack of attention given to two women who have both lost a son is also interesting and might add a different dimension to how we read this chapter if it were to be considered. See also Esther Fuchs (1989) The literary characterization of mothers and sexual politics in the Hebrew Bible. Semeia 46: 151-166.

8. Meyers (2005) Exodus, 42. 
Pharaoh sees the baby, his sister seizes the opportunity to suggest that she get a Hebrew wet nurse for her. The girl's words 'shall I get a nurse . . . for you?' indicate that the daughter of Pharaoh had already decided to keep the child and thus the sister's words are presented as acting on behalf of the princess. ${ }^{9}$ Although the fact that Moses' birthmother appears as his wet nurse is surely ironic, it may also signal the daughter of Pharaoh's status and her claim to be his mother. Childs observes that with regard to wet-nursing, in the Ancient Near East and Akkadian in particular, the "legal principle involved is that the right of possession belongs to the one paying for the child's upbringing, ${ }^{10}$ Childs argues that Exod. 2:1-10 shows awareness of traditional adoption formulae, as it includes the task of the nurse (weaning), a wage, and that the temporal reference 'when the boy grew up' (2:10) implied a fixed term for the weaning. ${ }^{11}$ For Childs, then, the daughter of Pharaoh would have been legally the baby's mother despite handing him over to his birthmother for nursing.

In addition, Bridge has recently highlighted the importance of mothers in biblical tradition being shown in their naming of children, which is more common than their fathers naming them. ${ }^{12}$ Notably, here it is the daughter of Pharaoh that names Moses, not his birthmother nor his father; Exod. 2:10 states that the daughter of Pharaoh called him Moses because he was drawn out of water. ${ }^{13}$ While Moses was originally an Egyptian name often combined with the name of a deity (e.g. Thutmose), the narrative presents the Egyptian princess as knowing Hebrew. ${ }^{14}$ Thus, the name itself combines Egyptian and Hebrew ideas and the process by which it is given reflects this, being given by an Egyptian woman to a Hebrew boy, and 'symbolizes the youth's membership in two communities' ${ }^{15}$ It is possible, then, that the daughter of Pharaoh giving Moses his name could simply be a literary construction designed to explain the origins of Moses' name, to tie him to two communities, or to foreshadow later events at the Reed Sea. ${ }^{16}$ However,

9. Houtman (1993) Exodus, Volume 1, 284.

10. Brevard S. Childs (1965) The birth of Moses. Journal of Biblical Literature 84: 109-122, here 112; and see also Gale A. Yee (2009) "Take this child and suckle it for me": Wet nurses and resistance in ancient Israel. Biblical Theology Bulletin 39: 180-189, here 182-185.

11. Childs (1965) The birth of Moses, 112-114.

12. Edward J. Bridge (2014) A mother's influence: Mothers naming children in the Hebrew Bible. Vetus Testamentum 64: 389-400.

13. Houtman notes that later commentators did not leave Moses nameless during his early (weaning) years. Pseudo-Philo, for example, named him Melchiel; Houtman (1993) Exodus, Volume $1,289$.

14. J.P. Hyatt (1980) Exodus. NCBC; London: Marshall, Morgan \& Scott, 64-65.

15. Meyers (2005) Exodus, 44.

16. Noth argued that the authors of Exodus evidently did not understand the Egyptian origins of Moses' name and so inserted an explanation (Noth (1962) Exodus, 26), and Durham agrees (Durham (1987) Exodus, 17). Meyers notes that the "drawing out" may foreshadow the Israelites' escape at the Reed Sea (Meyers (2005) Exodus, 44) and Bodner notes the irony of the Hebrew boy being drawn out of the waters by an Egyptian here, with the reversal at the Reed Sea wherein an Egyptian Pharaoh died; Keith Bodner (2019) An Ark on the Nile: Beginning of the Book of Exodus. Oxford: Oxford University Press, 112-116. As Bodner cogently observes, the naming of Moses both preserves the memory of events but also prompts the reader to look forward (Bodner (2019) Ark on the Nile, 115-116). Only later on do readers realise the full significance of Moses' name. 
while these explanations are plausible, I contend that it also signals the daughter of Pharaoh's status - as a mother, she named her son. ${ }^{17}$

The biblical text further states that when Moses was older, his birthmother returned him to the daughter of Pharaoh 'and he was to her for a son' (ויהי-לה לבן; Exod. 2:10). This language is different to that seen in the other clear example of Hebrew Bible adoption: namely, the adoption of Esther by her uncle Mordechai. There, Mordechai 'took' (לקח) Esther to be his daughter (Est. 2:7, 15). However, Exod. 2 bears some resemblance to 2 Sam. 7:14, where Yahweh says of David's son that 'I, I will be to him for a father' (אני אהיה -לו לאב). ${ }^{18}$ Although the relative lack of examples of adoption in the Hebrew Bible make any firm conclusions about adoption processes and language difficult to draw, the different language used in Exod. 2:10; 2 Sam. 7:14 may be because both the princess and Yahweh are adopting a figure from outside the family, whereas most other examples of biblical adoption are intra-familial. ${ }^{19}$ Further parallels between the daughter of Pharaoh and Yahweh are noted by Fretheim, with regard to Exod. 2:23-25; 3:7-8. ${ }^{20}$ Linguistically, these parallels are limited to the princess 'seeing' the ark (2:5) and Yahweh 'seeing' the Israelites' suffering $(2: 25 ; 3: 7)$; however, the thematic parallels are more persuasive. Both the princess and Yahweh hear cries (2:6; cf. $3: 7)$, see people suffering (2:5; cf. 2:25; $3: 7)$, and respond with pity or mercy (2:6; cf. 3:7-8). Given Pharaoh's actions against the Hebrew people in Exod. 1, it is no small matter that his daughter's actions parallel those of the Hebrew deity. ${ }^{21}$ Indeed, the ways in which the actions of the Egyptian princess transcend ethnic boundaries is vital to the story. Her adoption of the baby reverses her father's edict, the name she gives him foreshadows his future, and Moses' upbringing in the royal household explains how he can act as leader of the Israelites and also have such close access to Pharaoh later on in the narrative.

Yet, the biblical text does not refer to her as Moses' mother. Instead, even after she seemingly decides to keep him (Exod. 2:7-8), the narrator reports that the baby's sister 'went and called the child's mother' (ותקרא את-אם הילד; Exod. 2:8b). I propose that there are three possible reasons for this, all of which may prove partially correct: first, that the lack of names for the female characters meant that the use of 'mother' for Moses' birthmother was necessary to distinguish between the two adult women. Second, that this may be an effort to acknowledge yet ultimately undermine Moses' Egyptian heritage, and third (perhaps similarly) that this may be an example of 'resistance literature'

17. So perhaps Exum (1983) "Let every daughter live," 78.

18. Interestingly, Houtman translates Exod. 2:10 differently - "she regarded him as her own son," yet he translates 2 Sam. 7:14 as Yahweh "will be a father" (Houtman (1993) Exodus, Volume $1,288)$. As can be seen from the Hebrew above, there is no strong linguistic reason for this translation change as both Exod. 2:10 and 2 Sam. 7:14 use the root (היה-to be/become), and this translation choice notably offers a reality to Yahweh's fatherhood - he will be - but not to the daughter of Pharaoh's motherhood - she is only mother in her own eyes. We will return to this issue below.

19. E.g., Est. 2:7, 15; Ruth 4:16-17; Gen 30:3.

20. Fretheim (2010) Exodus, 38.

21. Childs argues that the major theme of the narrative is the contrast between God's plan for the good of his people and the evil designs of Pharaoh (Childs (1974) Exodus, 14). If so, then the daughter of Pharaoh is clearly acting as part of God's plan. 
that Yee observes. Yee highlights the ways in which women function in nationalist discourse, and in Exod. 2 in particular, she argues that it is the clever Hebrew women who ultimately act to save their nation. ${ }^{22}$ While the midwives, birthmother, and sister are shrewd, clever, individuals, Yee offers a somewhat negative reading of the daughter of Pharaoh, whom she views as acting in stupidity to expose the weakness and foolishness of the Pharaonic house. ${ }^{23}$ While acknowledging the irony inherent in the daughter of Pharaoh undermining the Pharaonic house, I do not go as far as Yee here. The text states that the daughter of Pharaoh 'had pity/compassion' for the child and chooses to raise him at her own expense; this does not seem to me to be a negative image. What is interesting for our purposes, however, is the way in which the daughter of Pharaoh's motherhood is written out of the narrative. Not only is she never called 'mother', but Exod. 2:10-11 skips Moses' entire upbringing and he suddenly appears in Exod. 2:11 as a man, able to kill another in a fight. Any input the daughter of Pharaoh had in these years is written out of story and history, and any benefit of Moses' adoptive upbringing is minimised, which may be part of the narrative of foreign royal/imperial benevolence that the authors sought to resist. ${ }^{24}$ Equally, it may point to either a lack of information, which would not be surprising given the distance between the Hebrew author and a child in the Egyptian royal household, or it may signal that this narrative is purely a literary construction and the characters play the role assigned to them. Perhaps as the author wished to emphasise his Hebrew, Levite, roots, the Hebrew birthmother is deemed the official mother and the Egyptian princess is denied the title.

\section{Un-Mothering in Biblical Scholarship}

Due to the lack of information given about her in the text, readers, writers and artists have all reacted to the daughter of Pharaoh differently. Langston traces the development of portrayals of the princess, observing that some, such as the medieval Pirke de Rabbi Eliezer, considered her worthy of eternal life for saving Moses, while others, such as Gregory of Nyssa, presented her as 'opposed to the Church's milk'. ${ }^{25}$ In addition, Langston notes a tendency in sixteenth- to nineteenth-century artworks to represent the princess as aloof, wealthy, and uncaring for the baby, while twentieth century and modern artworks are more sympathetic to her, portraying her as caring and compassionate. ${ }^{26}$ Consequently, it seems that responses to the daughter of Pharaoh are often informed and affected by socio-cultural events in our own times and experiences. This is evident in some modern American ministry groups using the daughter of Pharaoh as a symbol of defiant adoption - defying governmental orders to adopt a baby from another race and

22. Yee (2009) "Take this child," 185-189.

23. Yee (2009) "Take this child," 187-188.

24. Yee (2009) "Take this child," 185-189.

25. Scott M. Langston (2006) Exodus through the Centuries. Blackwell Bible Commentaries; Oxford: Blackwell, 2006, 25-26.

26. Langston (2006) Exodus through the Centuries, 26-29. 
giving him the qualities he would need to become a great leader. ${ }^{27}$ The ambiguity of the daughter of Pharaoh has also resulted in the ambivalence towards her found in biblical scholarship. Some commentators see the princess playing a vital role in the story (along with the sister and birthmother). ${ }^{28} \mathrm{~A}$ few other commentators, such as G. Henton Davies, barely mention her at all. ${ }^{29}$ As examples, Cole offers only the briefest of comments on the princess and chooses to stress the importance of Moses' early years for the formation of his identity, thereby downplaying the daughter of Pharaoh's significance in Moses' life. ${ }^{30}$ Slightly differently, Van Seters offers a redactional comment, noting that the princess' words in v6 lead directly into v7 but says nothing further on her, though he affords the Hebrew midwives a paragraph. ${ }^{31}$ Even within commentaries and works that offer some discussion of her character, the reception of the princess is at times divided: some scholars view her as stupid, the butt of anti-Egyptian authorial jokes, while others view her as a 'righteous gentile' - a symbol of foreign contribution to Israel's history. ${ }^{32}$

What many works have in common, however, is a reluctance to afford the adoptive mother the same level of maternal language, affection, and positivity as the birthmother. While this is, in part, due to our lack of understanding of the technicalities of adoption in ancient Israel, it may be pertinent to reflect further on the language we use. For example, consider this quote from Durham,

[Moses] is treated with maternal kindness by the daughter of the very king who had condemned him and to whose descendants he would become a nemesis, and is assigned as a responsibility with pay to the one woman in all the world who most wanted the best for him, his own mother. ${ }^{33}$

For Durham, the daughter of Pharaoh acts with 'maternal kindness', while the birthmother is elevated above the princess as the 'one woman in all the world who most wanted the best for him'. There is a clear hierarchy here - the birthmother is the ideal mother, elevated above any other claimants and, consequently, the adoptive mother becomes a passable (though kindly) second option. While Durham's sentiment is understandable in some ways, this

27. In particular, Langston references the Focus on the Family Ministries, which use the Moses story as one to help convey respect and dignity to adopted children, and The Moses Project, which emphasises the daughter of Pharaoh's defiance of government policies; Langston (2006) Exodus through the Centuries, 30-31.

28. E.g., Exum (1983) "Let every daughter live"; Meyers (2005) Exodus; Fretheim (2010) Exodus.

29. G. Henton Davies (1967) Exodus: Introduction and Commentary. London: SCM Press deals with the passage on 63-64, yet does not mention the daughter of Pharaoh at all.

30. Alan Cole (1973) Exodus: An Introduction and Commentary. Tyndale Old Testament Commentaries; London: Tyndale Press, 58.

31. John Van Seters (1994) The Life of Moses: The Yahwist as Historian in Exodus-Numbers. Louisville, KY: Westminster John Knox Press, 24-29. Although Van Seters' work is not a standard commentary, given the title The Life of Moses, it seems ironic that one of Moses' mothers is absent.

32. As noted above, Yee takes a more negative view of the princess (Yee (2009) "Take this child," 187-188), while Exum views her as a righteous gentile, being prompted by the sister rather than deceived (Exum (1983) "Let every daughter live," 80-81).

33. Durham (1987) Exodus, 17. 
language goes far beyond the text, which mentions little of the emotions of these woman. ${ }^{34}$ In fact, the most direct reference to the emotions of either woman would be found in the daughter of Pharaoh 'taking pity' on the child (Exod. 2:6). I wonder also, if this sort of language may be unhelpful for discourse about adoption in faith communities, for it implicitly assigns an adoptive mother a status below a birthmother. For can an adoptive mother not want the best for her child in the same way as a birthmother? Why is the daughter of Pharaoh to be viewed differently here? Was it her adoption rather than natural conception, her different race, or her higher level of wealth that rendered her less caring than the Hebrew birthmother? Perhaps a little more caution in comparisons between the two would be wise.

Alternatively, as we cannot say for certain whether Moses was named the princess' heir or not, Houtman even considers the daughter of Pharaoh a foster-mother rather than an adoptive mother. This is problematic too, for although Houtman is correct to apply sensitivity to the text, foster care is usually intended to be a temporary arrangement and there is no indication here that the daughter of Pharaoh took Moses in with the intention of him leaving in future. In addition, as noted above (n. 16), Houtman translates Exod. 2:10 as 'she regarded him as her own son', yet translates 2 Sam. 7:14 as '[Yahweh] will be a father to David's son and he will be a son to him'. ${ }^{35}$ This is an interesting difference, as 2 Sam. 7:14 and Exod 2:10 use the same root verb (היה, to be/become), yet Houtman translates Yahweh's fatherhood as more definite - he will be a father - despite the context speaking of a deity and a mortal, and the daughter of Pharaoh's motherhood as more subjective - she regarded him as a son - despite adoption being a known, practised situation between two humans. This is a small difference but one that, in effect, downplays the daughter of Pharaoh's motherhood. Another way in which her importance is downplayed is found in the amount of discussion given to other characters and other subjects at her expense. Often one finds the Hebrew midwives, the links with exposed child narratives, the birthmother's creation of the ark/basket, and source criticism to be at the forefront of discussions. ${ }^{36}$ While these all, of course, deserve consideration, I contend

34. This is notable, as Kozlova's study draws attention to the intensity of maternal grief. Kozlova argues that maternal grief was known to be powerful and thus could be implemented paradigmatically (see Kozlova (2017) Maternal Grief, esp. 37-43). Yet in Exod. 2, two women lose a son and their responses are not noted in the highly androcentric perspective of the author.

35. Houtman (1993) Exodus, Volume 1, 288. Interestingly, Boecker views 2 Sam. 7:14 as an example of an adoption formula (Hans Jochen Boecker (1974) Anmerkungen zur Adoption im Alten Testament. Zeitschrift für die alttestamentliche Wissenschaft 86: 86-89). Notably, Exod. 2:10 is closer to this formula than it is to the language seen in the Book of Esther and elsewhere.

36. For examples of works on the midwives see Rosalind Janssen (2018) A new reading of Shiphrah and Puah - Recovering their voices. Feminist Theology 27: 9-25 and H. Rand (1970) Figure-Vases in ancient Egypt and Hebrew midwives. Israel Exploration Journal 20: 209212. On source criticism and the textual development of Exodus 1-2 see, for example, Joel S. Baden (2012) From Joseph to Moses - The narratives of Exodus 1-2. Vetus Testamentum 62: 133-158; Donald W. Wicke (1982) The literary structure of Exodus 1:2-2:10. Journal for the Study of the Old Testament 24: 99-107. On Sargon and Moses' birth legend see, for example, H. Gressmann (1913) Moses und seine Zeit: ein Kommentar zu den Mose-sagen. Göttingen: Vandenhoeck \& Ruprecht; Colette Briffard (2010) Moïse versus Sargon. Vetus Testamentum 60: 479-482; and further discussion in, for example, Childs (1974) Exodus, 8-14. 
that they have also contributed to an accidental downplaying of the daughter of Pharaoh's motherhood. More words have probably been written on Sargon of Akkad's origin story and it's debatable connection with the Moses legend than have been written on Moses' adoptive mother.

\section{Speaking of Mothers}

To be sure, not all scholars so obviously relegate the adoptive mother or show preference for the birthmother, and indeed, some works offer insightful, considerate, and helpful discussion of the daughter of Pharaoh. ${ }^{37}$ But it is interesting to think about why the motherhood of this woman is often downplayed. Part of the answer, I suspect, is found in the biblical texts' lack of comment on Moses' adoptive upbringing after he is returned to the princess by his birthmother. The jump from this handing over of the child to Moses the man in Exod. 2:11 creates a gap that only the reader's imagination can fill, and thus, how readers respond to the daughter of Pharaoh will vary and will be dictated by our perception of other factors. Another part, as noted above, may well come from the biblical text assigning the title of mother only to the Hebrew woman, which creates an implicit question as to the formal standing of the daughter of Pharaoh vis-à-vis the child. A third part likely comes from the Egyptian ethnicity of the adoptive mother and the way Egypt is portrayed, especially Moses' opposition to it later on. We may hesitate to view an Egyptian positively, as so often the Egyptians represent an enemy in the biblical texts. This is also not helped by the fact that the daughter of Pharaoh is unnamed, meaning that the main information readers have about her is her connection to the evil Pharaoh who ordered the Israelite boys to be killed. Even if this woman acts in defiance of this order, her name ties her inextricably to the royal household and the people that would later prove so problematic for the Israelites; her name may prohibit her full redemption. In addition, this daughter of Pharaoh may also not be helped by the presence of another daughter of Pharaoh in the Hebrew Bible, whom King Solomon married in 1 Kgs. 3:1 and whose presence contributed to Solomon being led astray and worshipping idolatrous gods (1 Kgs. 11:1). Solomon's wife is more readily found in scholarship and the name of this more notorious woman may implicitly inform some readers' perceptions of the daughter of Pharaoh in Exod. 2.38

Finally, I suspect that a lack of awareness or experience of adoption itself has contributed, at times, to a lack of consideration in the language used to speak about this adoptive mother. For many readers of the biblical texts, who have not experienced the traumas that adoption can involve, it may not be so obvious to reflect on the daughter of Pharaoh as an adoptive mother, dealing with an inter-racially adopted son against a background of conflict. Notably, when the two mothers are in this narrative (Exod. 2:1-10), the picture

37. In particular, Bodner (2019) Ark on the Nile; Fretheim (2010) Exodus; Exum (1983) "Let every daughter live."

38. See, for example, Tal Davidovich (2010) Emphasizing the daughter of Pharaoh. Scandinavian Journal of the Old Testament 24: 71-84; Yong Ho Jeon (2011) The retroactive re-evaluation technique with Pharaoh's daughter and the nature of Solomon's corruption in 1 Kings 1-12. Tyndale Bulletin 62: 15-40. 
is tranquil; the baby is surrounded by women that want the best for him and protect him. Once the baby grows up, and male actors become the focal point of the narrative, violence reappears immediately. Moses' first action upon growing up is to kill a man and hide the evidence which results in Pharaoh trying to kill him (Exod. 2:15), and Moses having to flee the country (Exod. 2:15b-16). The daughter of Pharaoh is no longer in view, and she can protect him no longer. This is a narrative of motherhood; once children grow up, they go their own way. While Moses eventually finds his way and becomes one of the heroes of the Bible and a great symbol for adoptees to identify with, the daughter of Pharaoh is often forgotten once readers move beyond Exod. 2:10. She who took the baby out of danger, made him her son and provided him with the tools to become a great leader, fades from view and is even regarded negatively in some circles. Yet, it is through her motherhood that Moses survives. I argue therefore, that even without a full understanding of adoption in ancient Israel and Egypt, we should emphasise the motherhood of the daughter of Pharaoh when reflecting on Moses' origins, celebrating adoptive parents as we do so. The difficulties of adoption for adoptees is widely acknowledged, but the difficulties adoptive parents face often goes unspoken, yet the daughter of Pharaoh gives us an example of a biblical figure who played a major role in Israel's history through adopting a child.

\section{Concluding Remarks}

The preceding discussion has attempted to show that although - for all intents and purposes - the daughter of Pharaoh functions as Moses' adoptive mother, her motherhood is downplayed in text and scholarship. As a result, she often falls through the gaps, rarely, if ever, appearing in studies of biblical motherhood. I have proposed that this may be partly because the Hebrew birthmother, rather than the daughter of Pharaoh, is explicitly called 'mother', which leaves the status of the daughter of Pharaoh slightly open. In addition, while her association with the Pharaoh and Egypt is vital for the narrative, it leaves a lingering suspicion over her character. No matter the kindness she shows, she is inextricably tied to those who are in opposition to Israel. These elements seem to contribute to a certain ambivalence towards her found in biblical scholarship, which at times does not seem to afford this adoptive mother the same positivity as the birthmother receives. As a consequence, I have called attention to the ways in which the daughter of Pharaoh's motherhood is written out of discussions, so that we might reconsider it anew. Notably, reflecting more on the daughter of Pharaoh as a mother might permit us to consider this different portrayal of Egypt in the Book of Exodus a little more. Throughout much of the Exodus narratives Egypt is depicted as cruel, tyrannical, and anti-Hebrew. Yet, the daughter of Pharaoh offers an example of a different perspective: not all Egyptians treated the Hebrews badly. This accords with statements found elsewhere which instruct Israel to treat 'the ger' (גר-often translated as sojourner, resident alien, migrant) with kindness and respect, 'for you [Israel] were gerim in the land of Egypt' (e.g. Exod. 22:21; 23:9). Deuteronomy 23:7 even instructs Israel not to abhor the Egyptians because they had previously been gerim in their land. Evidently not all memories of Israel's sojourn in Egypt were tied to narratives of tyrannical rule, slavery and mass murder (cf. Exod. 1:15-22). Considering the daughter of Pharaoh as a mother offers 
an opportunity to celebrate an example of adoption that resulted in a hero enacting Yahweh's plan for his people. Although the daughter of Pharaoh ultimately lost her son when he fled to Midian and then again when he led the Hebrews out of Egypt, it was her adoption of him that set him on this path. While we remember the son, we should also remember the sacrifice of his mothers, both birthmother and adoptive mother.

\section{Funding}

The author(s) received no financial support for the research, authorship, and/or publication of this article. 